\title{
Plant biotechnology in support of the Millennium Goals
}

\author{
Günther Hahne $\cdot$ Michael Horn · Ralf Reski
}

Published online: 30 January 2011

(C) Springer-Verlag 2011

In the year 2000, 189 heads of state came together at the United Nations Headquarters in New York and agreed on a set of time-bound measures in order to reduce extreme poverty in the world. With a deadline of 2015, they have become known as the Millennium Goals. The eight adopted goals are:

1. Eradicate extreme poverty and hunger

2. Achieve universal primary education

3. Promote gender equality and empower women

4. Reduce child mortality

5. Improve maternal health

6. Combat HIV/AIDS, malaria and other diseases

7. Ensure environmental stability

8. Develop a global partnership for development.

A recent assessment by the United Nations (UNDP 2010) of the progress made since the adoption of the goals shows that resources and know-how to achieve the goals exist. However, progress is not equal in all countries, and acceleration is needed especially in Africa if the goals are to be met within the set time frame. Among the key messages of this report "...high per capita growth driven by agricultural productivity..." is singled out as one of the key

G. Hahne $(\bowtie)$

IRD - Institut de Recherche pour le Développement,

Marseille, France

e-mail: plantcellreports@ghahne.fastmail.fm

M. Horn

Noblesville, IN, USA

e-mail: mhornpcr@gmail.com

R. Reski

Plant Biotechnology, Faculty of Biology, University of Freiburg,

Schaenzlestr. 1, 79104, Freiburg, Germany

e-mail: ralf.reski@biologie.uni-freiburg.de factors to promote progress towards the reduction of poverty in the world.

Many components contribute to progress in agricultural productivity, including advances in education, infrastructures, the socio-economic environment, technical engineering, optimization of agricultural input and agronomic practices, and reduction of pre- and post-harvest losses. The market demands a delicate equilibrium between quantitative and qualitative aspects of the production; the most appropriate type of production (subsistence or market-oriented farming, food or non-food crops, etc.) depends on a complex mix of local factors.

Historically, two components have almost equally contributed to progress in agricultural productivity: (1) technical advances (engineering, chemical, etc.) and (2) advances in the understanding of the biological background and its application (genetics, plant physiology, biology of biotic and abiotic stress, defence against predators, etc.). Further significant progress in the second component cannot be imagined without a comprehensive understanding of the involved biology on the molecular level, and its application in the multiple forms of biotechnology.

While biotechnology is a highly sophisticated process requiring a certain critical mass of intellectual, technical and financial resources, many of its products are robust and easy to handle under harsh conditions. Tailor-made solutions to particular problems appear more and more feasible while biosafety issues and economic considerations are part of the constraints that need to be observed and respected before large-scale application of the products of biotechnology can be envisaged.

Ever since its creation, it has been the prime objective of Plant Cell Reports to accompany and facilitate the emergence of the knowledge that forms the basis of current plant biotechnology. It is the objective of this special issue 
to provide a snapshot view of today's state-of-the-art of plant biotechnology with respect to the contribution it can make to improve the livelihoods of the poorest citizens of the world and to achieve the Millennium Goals.

To this end, the present issue assembles original articles that are representative of the scientific questions and results that collectively form the knowledge base for future breakthrough technologies in support of agricultural productivity increases in low-income countries. The patchwork picture provided by the original articles is rounded off by a collection of reviews that summarize significant steps and provide perspectives for future development. This objective overview is completed by opinion papers which express more personal views of their authors and thus highlight the benefits that can be expected from largescale use of biotechnological techniques and products in low-income countries and harsh climatic conditions, and the problems that may arise from this development.

The project of this special issue has met with an overwhelming response. The number of high-quality contributions by far exceeds the capacity of a single issue of Plant Cell Reports. In consequence, the articles addressing the Millennium Goals will be published in two separate issues. In the present issue, the subject is introduced by the opinion paper by Yuan et al. (2011), reflecting on the potential impact of plant biotechnology on each of the eight Millennium Goals. Wang et al. (2011) review the applications and possibilities of recombinase technology, while Balestrazzi et al. (2011) consider the impact of genotoxic stress and DNA repair mechanisms for improving crop productivity. Progress related to drought-responsive genes in rice is reviewed by Hadiarto and Tran (2011). Plant parasitic nematodes and control strategies based on natural and induced plant resistance are reviewed by Molinari (2011). A new method for rapid evaluation of insect resistance of transgenic plants is presented by Leckie and Stewart (2011). Yu et al. (2011a) present the development and characterization of SSR markers for the breeding of rubber trees. Differential gene expression associated with resistance to a fungal disease in cucumber is addressed by Li et al. (2011), while transgenic watermelons resistant to two important viral diseases are presented by Yu et al. (2011b). Arabidopsis is the model used for a study by Yang et al. (2011) of how the BnLAS gene affects plant development and drought tolerance. Other important yield-limiting stresses include cold, salt and oxidative stresses. These are the subject of the article by Zhang et al. (2011) which focuses on the example of tomato, while Sato et al. (2011) address the problem of chilling tolerance in rice. The problem of expressing pharmacologically active peptides in plants is addressed in the study by Luchakivskaya et al. (2011) and Soria-Guerra et al. (2011). Finally, Subramanyam et al. (2011) and
Basnayake et al. (2011) present progress towards the transformation of banana and diverse sugarcane cultivars, respectively.

The two special issues devoted to the Millennium Goals are intended to be a contribution of the concerned scientific community to the discussion about the impacts of biotechnology for the world-wide reduction of misery. An experts' view, one of many, showing current research interests in the field and from which a view may emerge of future directions that the field may take; and which may become one of the elements that contribute to reaching the Millennium Goals.

\section{References}

Balestrazzi A, Confalonieri M, Macovei A, Donà M, Carbonera D (2011) Genotoxic stress and DNA repair in plants: emerging functions and tools for improving crop productivity. Plant Cell Rep 30 (in this issue). doi:10.1007/s00299-010-0975-9

Basnayake SWV, Moyle R, Birch RG (2011) Embryogenic callus proliferation and regeneration conditions for genetic transformation of diverse sugarcane cultivars. Plant Cell Rep 30 (in this issue). doi:10.1007/s00299-010-0927-4

Hadiarto T, Tran LP (2011) Progress studies of drought-responsive genes in rice. Plant Cell Rep 30 (in this issue). doi:10.1007/ s00299-010-0956-Z

Leckie BM, Stewart CN Jr (2011) Agroinfiltration as a technique for rapid assays for evaluating candidate insect resistance transgenes in plants. Plant Cell Rep 30 (in this issue). doi:10.1007/s00299010-0961-2

Li JW, Liu J, Zhang H, Xie CH (2011) Identification and transcriptional profiling of differentially expressed genes associated with resistance to Pseudoperonospora cubensis in cucumber. Plant Cell Rep 30 (in this issue). doi:10.1007/s00299-010-0959-9

Luchakivskaya Y, Kishchenko O, Gerasymenko I, Olevinskaya Z, Simonenko Y, Spivak M, Kuchuk M (2011) High-level expression of human interferon alpha-2b in transgenic carrot (Daucus carota L.) plants. Plant Cell Rep 30 (in this issue). doi: 10.1007/s00299-010-0942-5

Molinari S (2011) Natural genetic and induced plant resistance, as a control strategy to plant-parasitic nematodes alternative to pesticides. Plant Cell Rep 30 (in this issue). doi:10.1007/ s00299-010-0972-Z

Sato Y, Masuta Y, Saito K, Murayama S, Ozawa K (2011) Enhanced chilling tolerance at the booting stage in rice by transgenic overexpression of the ascorbate peroxidase gene, OsAPXa. Plant Cell Rep 30 (in this issue). doi:10.1007/s00299-010-0985-7

Soria-Guerra RE, Rosales-Mendoza S, Moreno-Fierros L, LópezRevilla R, Alpuche-Solís AG (2011) Oral immunogenicity of tomato-derived sDPT polypeptide containing Corynebacterium diphtheriae, Bordetella pertussis and Clostridium tetani exotoxin epitopes. Plant Cell Rep 30 (in this issue). doi:10.1007/ s00299-010-0973-y

Subramanyam K, Subramanyam K, Sailaja KV, Srinivasulu M, Lakshmidevi K (2011) Highly efficient Agrobacterium-mediated transformation of banana cv. Rasthali $(\mathrm{AAB})$ via sonication and vacuum infiltration. Plant Cell Rep 30 (in this issue). doi: 10.1007/s00299-010-0996-4

UNDP (2010) What Will it take to achieve the millennium development goals?-An International Assessment. UNDP 
Report. http://content.undp.org/go/cms-service/stream/asset/?asset_ id $=2620072$

Wang Y, Yau YY, Perkins-Balding D, Thomson JG (2011) Recombinase technology: applications and possibilities. Plant Cell Rep 30 (in this issue). doi:10.1007/s00299-010-0938-1

Yang M, Yang Q, Fu T, Zhou Y (2011) Overexpression of the Brassica napus BnLAS gene in Arabidopsis affects plant development and increases drought tolerance. Plant Cell Rep 30 (in this issue). doi:10.1007/s00299-010-0940-7

Yu F, Wang BH, Feng SP, Wang JY, Li WG, Wu YT (2011a) Development, characterization, and cross-species/genera transferability of SSR markers for rubber tree Hevea brasiliensis. Plant Cell Rep 30 (in this issue). doi:10.1007/s00299-0100908-7

Yu TA, Chiang CH, Wu HW, Li CM, Yang CF, Chen JH, Chen YW, Yeh SD (2011b) Generation of transgenic watermelon resistant to Zucchini yellow mosaic virus and Papaya ringspot virus type W. Plant Cell Rep 30 (in this issue). doi:10.1007/s00299-0100951-4

Yuan D, Bassie L, Sabalza M, Miralpeix B, Dashevskaya S, Farre G, Rivera SM, Banakar R, Bai C, Sanahuja G, Arjó G, Avilla E, Zorrilla-López U, Ugidos-Damboriena N, López A, Almacellas D, Zhu C, Capell T, Hahne G, Twyman RM, Christou P (2011) The potential impact of plant biotechnology on the Millennium Development Goals. Plant Cell Rep 30 (in this issue). doi: 10.1007/s00299-010-0987-5

Zhang C, Liu J, Zhang Y, Cai X, Gong P, Zhang J, Wang T, Li H, Ye $\mathrm{Z}$ (2011) Overexpression of SlGMEs leads to ascorbate accumulation with enhanced oxidative stress, cold, and salt tolerance in tomato. Plant Cell Rep 30 (in this issue). doi:10.1007/s00299010-0939-0 